\title{
After libyan war: health and environmental research exist or not?
}

Keywords: Libyan war, Health, Environmental impact, Pollution, Contamination, Exploded site, Wastes after war

Abbreviations:XRD, X-Ray Diffraction; XRF, X-Ray Flourscience; ICP, Inductively Coupled Plasma; AA, Atomic Absorption; IC, Ion Chromatography; GC, Gas Chromatography; HPLC, High Performance Liquid Chromatography; DTA, Differential Thermal Analysis; GTA, Gravimetric Thermal Analysis

\section{The Libyan War}

Libya is a large Arabic country in the north of Africa, it has a longest coast on Mediterranean sea, the coast strip is about $\sim 2000$ $\mathrm{km}$. Libyan population is about 5-6 million. Through 40 years, Libya was governed by Colonel Muammar Gaddafi. In 17/2/2011 the Libyan revolution was ignited with the Arab Spring protests by the Libyan youth claiming for their freedom and took down the Libyan general's regime which affected hugely the economical state of the country that only depends on the oil as the main resource of the country's income alongside with the tourism which was affected too. Since this moment, the Libyan war started between different terminals. Along six years, a huge amount of gases, very fine particulates, inorganic/ organic chemicals, and unknown toxic substances were spread in the environment as a result of the war. Hence, the health and environment were affected greatly.

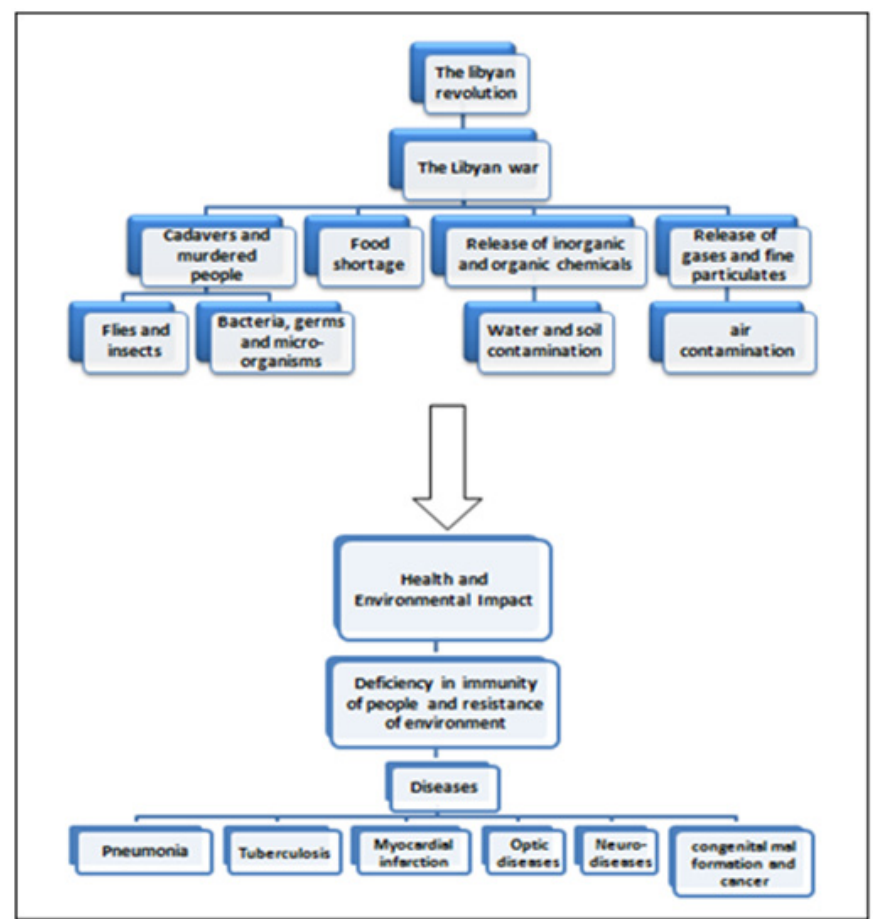

Figure I The relationship between the war, health and environmental impacts.
Volume 6 Issue 3 - 2017

Maher Mohamed Abed El Aziz

Department of Chemistry, University of Tripoli, Libya

Correspondence: Maher Mohamed Abed El Aziz, Department of Chemistry, University of Tripoli, Libya, Tel 00218924369783 Emailhrshr152@gmail.com

Received: August 04, 2017 | Published: October 12, 2017

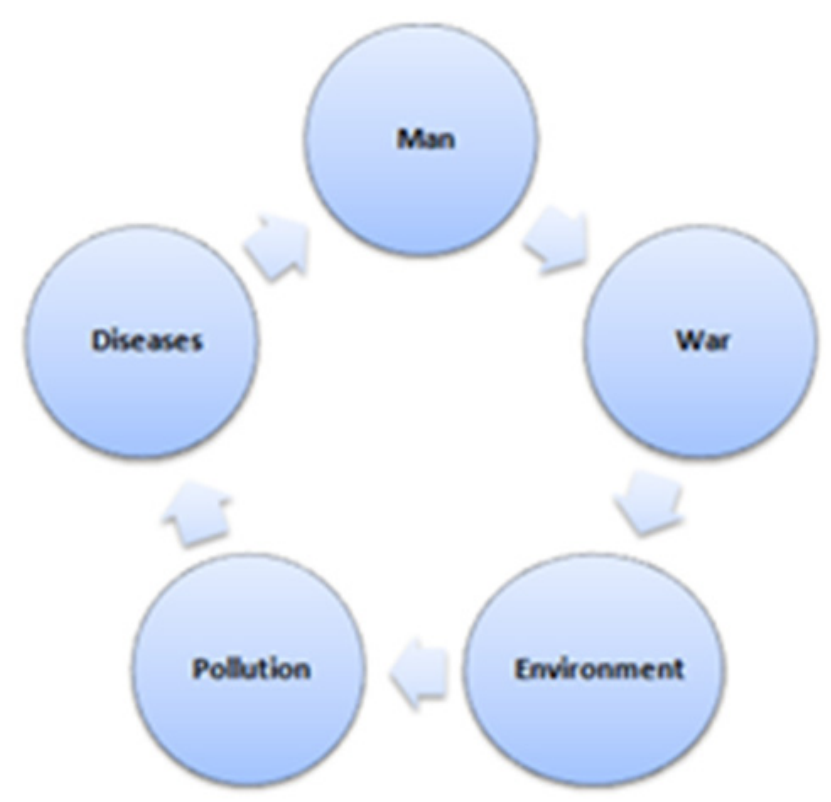

Figure 2 The Closed Cycle between Man, War, and Environment.

\section{Health and environmental impact}

As a foreign scientific researcher, I lived about 14 years in Libya (7 years in Benghazi and 7 years in Tripoli) and noticed differences of health and environmental impacts along this period of time such as: increasing in Pneumonia, Tuberculosis, Myocardial infarction (MI), Optic diseases, Neuro-diseases, and cancer. In general, most of diseases may be due to the deficiency in immunity of people and the deficiency in resistance of environment during the war. In some regions, Cadaver and murdered people also spread in the environment and roads for a long time as well as flies and insects. During the Libyan war, so many thousands of tons of explosives were used leading to air, water, and soil pollution. The relationship between man, 
environment, war and diseases can be described as the closed cycle or system (Figures $1 \& 2$ ).$^{1-5}$

\section{Human and environmental protection in Libya}

Our research team in Tripoli University aimed to establish a broad scientific research program or project to protect human being and environment now and in the future generation. The research team consists of two working groups:

I. Environmental group: Scientists (chemists, agronomist, and biologists)

II. Public health group: physicians

The plane of the first group depends on:

a. Collection of environmental samples from well known exploded sites.

b. Physical, chemical and biological analysis of the samples using XRD, XRF, ICP, AA, IC, GC, HPLC, DTA, GTA to detect and determine the concentration of toxic inorganic and/or organic materials as well as bacterial activates. Factors affecting the mechanism of distribution and migration of contaminants through the environment will be studied such as: concentration, depth, time, temperature, moister content and $\mathrm{pH}$ of the medium. Proposed cleaning or decontamination options will be provided according to the level of contamination, the type of contaminants and the financial aid.

c. Interpretation and analysis of the obtained results and writing a scientific manuscripts.

d. Publish the scientific manuscripts in international journals.

e. The plane of the second working group depends on the recording of abnormal diseases around the exploded area. In fact, the invitation is opened for the international communities and authorities to interact with us to undergoing this project by finance or scientific aid.$^{6-8}$

\section{In Brief}

On 19 March 2011, a multi-state NATO-led coalition began a military intervention in Libya. Military operations began, with American and British naval forces firing over 110 Tomahawk cruise missiles. NATO operation aimed to destroy the Gaddafi forces with their weapons including 30 heavy SAM batteries, 17 medium SAM batteries, 55 light SAM batteries, 400-450 launchers, and 440-600 short-ranged air-defense guns. In total, NATO and partner air assets had flown more than 26,000 sorties, an average of 120 sorties per day. Reports estimate about $42 \%$ of the sorties were strike sorties, which damaged or destroyed approximately 6,000 military targets. Fighting in Libya ended in late October following the death of Muammar Gaddafi, and NATO stated it would end operations over Libya on 31 October 2011. By the end of NATO operation, the Libyan civil war starts till now leaving dangerous wastes. Our working group starts a research program to study and evaluate the influences of the war wastes on human and environment ${ }^{8-11}$ This manuscript answers the following questions:

a. Who we are? We are a research group from the Libyan universities and research centers.

b. What is the aim of our program? The main aim is the protection of human and environment, now and in the future. c. How? By the analysis of environmental samples and the war waste samples. Studying the mass transfer mechanism, and contamination prevention.

d. What type of investigation and analysis? Chemical, biological, environmental and health analysis.

e. What is the procedure? Sampling, instrumental analysis, collection of the results, publish the obtained results of analysis.

f. What is the research program duration? 3 years, 36 months and 5 working days per week.

g. What is the expected output? The status of environmental contamination after Libyan war and proposed cleaning options for contaminated area.

h. Do we need support? Yes, from the globe.

i. What type of support? Financial, scientific and publishing.

j. Can anyone from the world share this program? Yes, why not? No problem?

$\mathrm{k}$. Who is the founder/organizer of this program? Dr. Maher Mohamed Abed El Aziz (Figure 3).

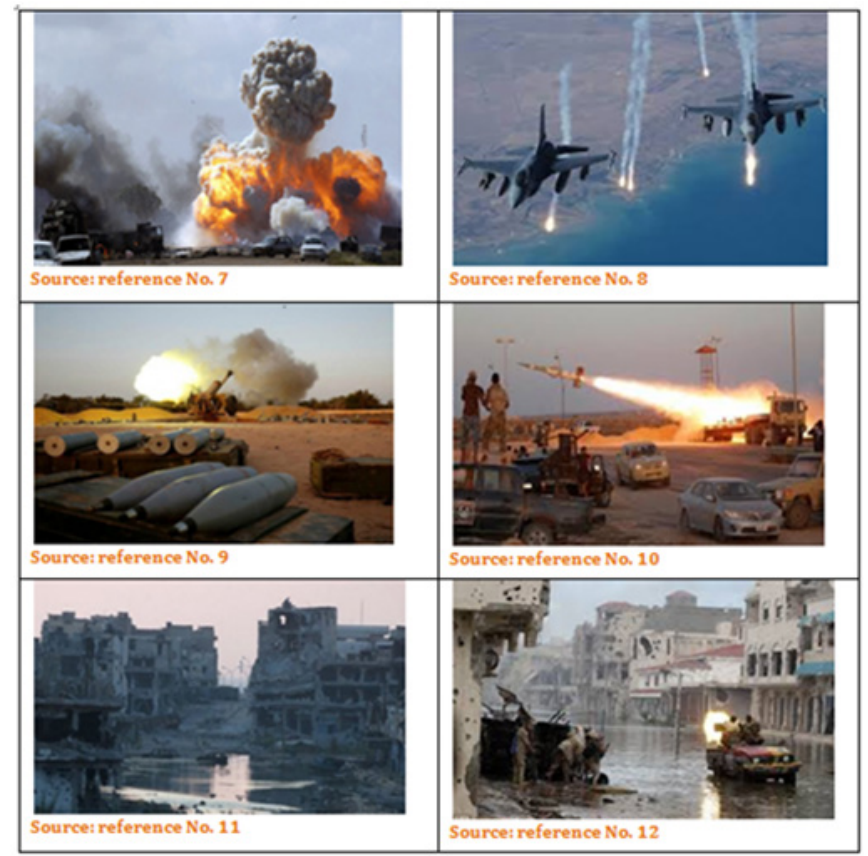

Figure 3 Libyan War in Pictures.

\section{Acknowledgments}

None.

\section{Conflicts of Interset}

None.

\section{References}

1. European Environmental Agency ENPI-SEIS project, Country ReportLibya. 2015

2. Saloume Bazyan Environmental impact of war technology and prohibition processes. Eco-technology and Environmental Science Department of Engineering and Sustainable Development. Mid Sweden University, Sweden, p. 2012;1-27. 
3. Harvard University and NATO The Libya Case Study. Working Paper of the collaborative NATO-Harvard project: Towards a Comprehensive Response to Health System Strengthening in Crisis-affected Fragile States, USA, p. 2013;1-63.

4. https://en.wikipedia.org/wiki/2011_military_intervention_in_Libya

5. NATO and Libya - Special Focus: Home, Libya.

6. Operation Unified Protector Final Mission Stats.

7. Military Intervention in Libya, Libya.
8. Defying all reason, NATO is shambling towards another disastrous war in Libya.

9. IS weakening but still a threat: Obama, USA

10. NATO Destruction of Libya, Libya.

11. A Certain Sort of Absurdity: the repatriation of corpses.

12. www.breitbart.com/national-security/2016/07/23/libya-battle-toforce-islamic-state-out-of-qaddafis-birthplace-continues 